\title{
A Role for a Chicken Homolog of the Neural Cell Adhesion Molecule L1 in Consolidation of Memory for a Passive Avoidance Task in the Chick
} \author{
Steven P.R. Rose ${ }^{2}$ \\ Brain and Behaviour Research Group \\ The Open University \\ Milton Keynes MK7 6AA, UK \\ ${ }^{1}$ Department of Neurobiology \\ Swiss Federal Institute of Technology \\ Honggerberg \\ CH-8093 Zurich, Switzerland
}

Andrew B. Scholey, Radmila Mileusnic, Melitta Schachner, ${ }^{1}$ and

\section{Abstract}

Intracranial injection of antibodies directed against the neural cell adhesion molecule $L 1$ resulted in amnesia for passive avoidance training in day-old chicks tested $24 \mathrm{hr}$ subsequently. L1 antibodies were amnesic when administered at one of two time windows: $30 \mathrm{~min}$ pretraining and 5.5-8 hr post-training. No amnesia was apparent if injections were made at times before, between, or after these time windows $(-2$, $+1,+3,+4$, or $+12 \mathrm{hr}$ relative to training). A fragment of the $\mathrm{L1}$ molecule derived from the external fibronectin domains FN1-5 produced amnesia only when injected at the 5.5-hr timepoint, whereas a fragment of the immunoglubin-like domains Ig I-VI produced amnesia only when injected 30 min prior to training. We have shown previously that long-term memory for the passive avoidance task requires two waves of glycoprotein synthesis, the first occurring immediately after training, and the second some $6 \mathrm{hr}$ thereafter. The glycoprotein synthesis inhibitor 2-deoxygalactose results in amnesia if injected at either time, whereas the neural cell adhesion molecule (N-CAM) is specifically involved only in the

${ }^{2}$ Corresponding author. second wave. The coincidence of the time course of memory disruption resulting from injection of $\mathrm{L1}$ antibodies with that occurring with 2-deoxygalactose supports the hypothesis that establishment of an enduring memory for the experience of passive avoidance training requires two waves of glycoprotein synthesis, each wave being biochemically and functionally discrete. The differential effects of the two L1 fragments suggests that separate mechanisms of synaptic stabilization are involved at the two time points.

\section{Introduction}

The synthesis of synaptic membrane glycoproteins appears to be a crucial step in the cellular cascade that subserves long-term memory formation (e.g., Rose 1989). Increased synaptic glycoprotein synthesis has been reported as a feature of neuronal plasticity in a variety of training paradigms, including rodent brightness discrimination (Popov et al. 1981), and passive avoidance training in both rats (Morgan and Routtenberg 1979) and chicks (Sukumar et al. 1980; Bullock et al. 1992). These results are reinforced by behavioral studies in which administration of the specific metabolic inhibitor of glycoprotein syntheis 2-deoxygalactose (2-D-gal) disrupted memory formation for a brightness discrimination task in the

LEARNING \& MEMORY 2:17-25 (c) 1995 by Cold Spring Harbor Laboratory Press ISSN1072-0502/95 \$5.00

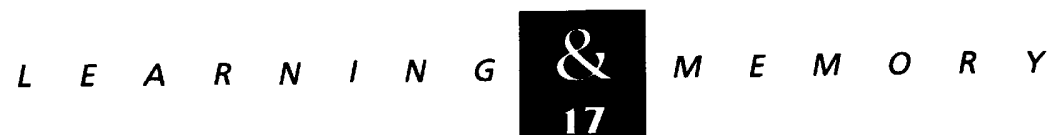


rat (Jork et al. 1986) and in a one-trial passive avoidance task in the chick (Rose and Jork 1987; Barber and Rose 1991; Scholey et al. 1993). In the chick, 2-D-gal was incorporated into and also blocked incorporation of labeled fucose into a number of pre- and postsynaptic membrane glycoprotein fractions that show enhanced fucosylation as a result of training (Bullock et al. 1990).

Complementing studies with "generic" inhibitors of glycoprotein synthesis such as 2-D-gal have been the identification of specific glycoproteins involved in memory formation that has relied largely on the use of antibodies raised against specific synaptic membrane glycoproteins. Thus, application of antibodies against a $45-\mathrm{kD}$ cell surface glycoprotein block both establishment and maintenance of long-term potentiation (Stanton et al. 1987), as does incubation with blockers of the integrin receptor (Staubli et al. 1990). Antiependymin antibodies inhibit consolidation of learning tasks in the goldfish (e.g. Piront and Schmidt 1988). In the chick, intracerebral injection of antibodies against the immunoglobulin superfamily glycoprotein Thy-1 resulted in amnesia for a passive avoidance task when administered around the time of training but not when examined at other times (Lappuke et al. 1987).

Training day-old chicks on a one-trial passive avoidance task, in which they learn to suppress their tendency to peck at a small bright bead if it is coated in the bitter-tasting methylanthranilate, results in a time dependent cellular and molecular cascade culminating in the remodeling of pre-and postsynaptic elements in two discrete regions of the forebrain, the intermediate medial hyperstriatum ventrale (IMHV) and the lobus parolfactorius (LPO) (for review, see Rose 1991). The cascade involves two distinct waves of glycoprotein synthesis, as evidenced by enhanced fucose incorporation, occurring in both IMHV and LPO at varying times following training. Both waves are necessary for long-term (i.e., $\geqslant 24 \mathrm{hr}$ ) memory. Retention for the avoidance task, in which amnesia is evidenced by chicks, which would otherwise avoid the previously bitter bead, pecking at a dry bead on test. Both waves are susceptible to intracranial 2-D-gal; if animals were tested $24 \mathrm{hr}$ following training, they exhibited amnesia only if 2-D-gal had been administered either around the time of training or 6-8 hr following training but not at other times outside these time windows (Scholey et al. 1993). Like the first time window, the second is also sensitive to the protein synthesis inhibitor anisomycin
(Freeman et al. 1995). However, antibodies to the neural cell adhesion molecule (N-CAM) resulted in amnesia only if they were injected during the second wave of glycoprotein synthesis (Scholey et al. 1993). A similar time window for anti-N-CAMinduced amnesia has been found following onetrial passive avoidance training in the rat (Doyle et al. 1992).

The neural cell adhesion molecule $L 1$ in the mouse [Ng-CAM, 8D9 or G4 as possible homologs in the chicken (Lagenaur and Lemmon 1987; Grumet 1992; Sonderegger and Rathjen 1992)] is an integral cell surface glycoprotein (Rathjen and Schachner 1984; Faissner et al. 1985) and was originally defined as an adhesion molecule because antibodies against it inhibited cell adhesion and aggregation (Faissner et al. 1985). Lemmon et al. (1989) showed that antibodies to chicken and mouse L1 block neurite outgrowth from mouse neurons, thus confirming that mouse and chicken L1 interact homophilically. Like N-CAM, L1 is localized to nerve growth cones and neuritic shafts of the developing central nervous system (CNS) (Persohn and Schachner 1987). It appears not to mediate synapse formation (Orkand et al. 1984) but is involved in neuron-neuron (but not neuron-astrocyte or astrocyte-astrocyte) contact (Keilhauer et al. 1985) and in mediating neurite fasciculation and outgrowth on L1-positive partner cells (Bixby et al. 1988; Seilheimer and Schacher 1988; Linneman and Bock 1989). L1 has been found only on postmitotic neurons where it is differentially expressed with respect to cell type, cellular compartment, and developmental stage. For example, on granule and Purkinje cells, L1 has been found on unmyelinated axons and transiently on cell bodies but not on dendrites (Persohn and Schachner 1987). First indications as to the functional specializations of the different domains of L1 for neuronal adhesion and neurite outgrowth have been obtained recently (Appel et al. 1993). From these observations it appears as if several domains are involved in each function and that the domains are overlapping but also functionally distinct.

Given the role of $\mathrm{L} 1$ in mediating cell-cell contact, the present study was undertaken to determine whether L1, or its chick homolog, is among the learning-associated glycoproteins participating in either or both waves of glycoprotein synthesis following passive avoidance training in the chick, and is necessary for memory formation. If so, antibodies to L1 administered at an appropriate time relative to training should prevent the

$$
\text { n....... }
$$


synaptic remodeling necessary for long-term memory and therefore produce amnesia for the task. Similarly, if the extracellular domains of the L1 molecule play a part in the recognition and adhesion processes that are required for synaptic remodeling and stabilization, exogenously applied extracellular domain fragments that will bind homophilically to the endogenous molecule might disrupt this process. Here, we report the effects of L1 antibodies and the extracellular fibronectin domains (FN1-5) and immunoglobulin-like domains (Ig I-VI) injected either pre- or post-training on recall for the passive avoidance task in chicks tested $24 \mathrm{hr}$ following training.

\section{Materials and methods}

\section{ANTIBODIES AND FRAGMENTS}

Polyclonal antibodies were prepared in rabbits by immunization with immunoaffinity-purified L1 (Ng-CAM, 8D9) following an established immunization procedure (Rathjen and Schachner 1984). L1 was isolated from 1-day-old chicken brains using an 8D9 monoclonal antibody (Lagenaur and Lemmon 1987) column, versus established procedures (Rathjen and Schachner 1984). Antibodies were isolated from the serum obtained after the third immunization using protein G-Sepharose (Pharmacia LKB) according to the manufacturer's instructions. Polyclonal antibody $\mathrm{R} 4$ was raised against a chick synaptic membrane fraction of 140-160 kD (Bullock et al. 1992) and recognizing major bands at 140,160 , and $220 \mathrm{kD}$ (Mileusnic et al. 1995). Recombinantly expressed fusion proteins in Escherichia coli, representing the six immnoglublin-like (I-VI) and five fibronectin type III homologous repeats (FN1-5) were prepared as described by Appel et al. (1993).

\section{SDS-PAGE AND IMMUNOBLOTS OF CHICK SUBCELLULAR FRACTIONS}

Fifty micrograms of protein from brain homogenate, crude membranes, a soluble fraction (Burchuladze et al. 1990), and postsynaptic densities (Murakami et al. 1986), all from day-old chicken brains, was separated by SDS-PAGE under reducing conditions on a 5-15\% polyacrylamide gradient gel (Laemmli 197) whereafter they were transferred to nitrocellulose according to the method of Burnette (1981). After overnight incubation with $L 1$ antibodies at a dilution of 1:1000 in Tris-buffered saline ( $\mathrm{pH} 7.2$ ), containing 5\% defatted milk powder, immunoreactive bands were detected according to previously described methods (Scholey et al. 1993).

\section{TRAINING AND TESTING PROCEDURES}

Day-old Ross chunky chicks of both sexes, hatched in our own incubators (Milton Keynes laboratory), were placed in pairs in small pens, pretrained to peck at small $(2.5 \mathrm{~mm})$ white beads, and then trained on a larger (4-mm) chrome bead coated with methylanthranilate as described by Lossner and Rose (1983). Birds that pecked the bitter bead evinced a stereotyped disgust response, shaking their heads vigorously and backing away from the bead. Twenty-four hours following training, each animal was tested by the presentation of a dry chrome bead identical to the one used in training. Retention of passive avoidance learning was indicated by animals avoiding the test bead. In each replication of this protocol 24-36 chicks were trained and tested. More than $80 \%$ of trained, uninjected chicks normally avoid the bead on test under these conditions, although there is sometimes a slight reduction in avoidance in saline-injected birds. In contrast, birds that are trained on a water-coated bead peck the dry bead avidly on test, and their avoidance score is rarely $>5 \%-10 \%$. All training and testing was routinely carried out by an experimenter blind as to the prior treatment of the animals.

\section{INJECTIONS}

L1 antibodies, antibody R4 and FN1-5 and Ig I-VI fragments were dialyzed overnight against $0.9 \%$ saline, and the concentration adjusted to 1 $\mathrm{mg} / \mathrm{ml}$ for $\mathrm{L} 1$ and $\mathrm{R} 4$ and $25 \mu \mathrm{g} / \mathrm{ml}$ for the fragments. Chicks received bilateral intracranial injections into the IMHV of $10-\mu \mathrm{l}$ antibodies or preimmune serum per hemisphere, control animals received similar injections of saline. Accurate delivery into the IMHV was achieved by the use of a specially designed head holder and sleeved Hamilton syringe (Davis et al. 1982). Because of

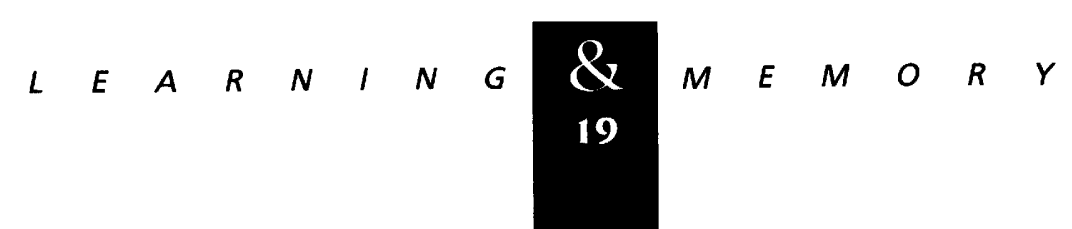


the unossified skull of the chick, such injections can be performed rapidly and without the need for surgery or anesthesia. Chicks receiving this injection volume of either saline or antibodies prior to training or testing showed no overt behavioral effects, pecking the bead accurately during training. The large extracellular volume of the brain of the newly hatched chick means that injections of this size are well-tolerated and can be achieved without leakage. As our previous report has demonstrated (Scholey et al. 1993) there is a slow diffusion of antibody from the injection site in the hours following injection. The accuracy of placement of the injection was routinely monitored by visual inspection of the brains postmortem. In each replication of the experiment, a balanced group of saline and antibody, or fragment-injected chicks, was employed. In the L1 experiment, groups of chicks were injected with saline or antibody at one of eight time points relative to training; $2 \mathrm{hr}$ or $30 \mathrm{~min}$ pretraining, or $+1,+3,+4$, $+5.5,+8$, or $+12 \mathrm{hr}$ post-training. On the basis of our previous observations we predicted that any effects would be observed in birds injected at either $30 \mathrm{~min}$ pre- or $5.5 \mathrm{hr}$ post-training, and the numbers of replications at these time points were accordingly greater $(n=17,28,17,19,18,29,19$, and 18, respectively, for controls; and $n=18,33$, $15,19,17,31,17$, and 19 , respectively, for antibody injections). L1 fragments FN1-5 and Ig I-VI were injected at either $-30 \mathrm{~min}$ or $+5.5 \mathrm{hr}$ and retention tested at $24 \mathrm{hr}$. Retention in groups of saline and L1-antibody or L1-fragment-injected chicks was compared statistically by $\chi^{2}$.

\section{Results}

\section{IMMUNOBLOTS}

Antibodies against chicken L1 recognized a major band with relative molecular mass of 140 $\mathrm{kD}$ in all fractions tested; brain homogenate, soluble fraction, crude membranes, and postsynaptic densities (Fig. 1) Minor bands running at 200 and $80 \mathrm{kD}$ were also observed. The $140-\mathrm{kD}$ proteolytic fragment (Sadoul et al. 1988) appeared as a densely staining band in homogenate and in both soluble and membrane fractions but was most concentrated in the postsynaptic density fraction prepared from day-old chicken brains.

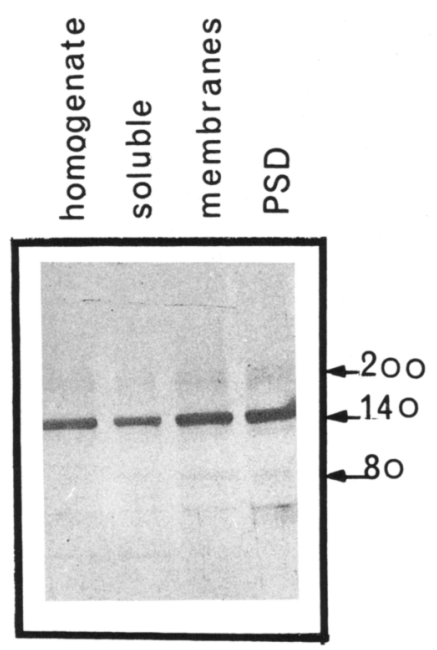

Figure 1: Immunoblots of homogenate, soluble fraction, crude membranes, and postsynaptic densities (PSD) from day-old chicken brains, transferred to nitrocellulose and stained with polyclonal anti-L1. Molecular masses in kilodaltons are indicated.

\section{EFFECT OF INTRACRANIAL INJECTIONS OF ANTIBODIES TO L 1}

When L1 antibodies were injected into the IMHV of day-old chickens at various time points before and after training, the birds were amnesic compared with saline-injected controls only in three groups when tested $24 \mathrm{hr}$ post-training (Fig. 2). These groups received L1 antibodies $30 \mathrm{~min}$ pretraining and 5.5 and $8 \mathrm{hr}$ post-training $\left(\chi^{2}=5.182,3.913\right.$, and 4.124, respectively, in all cases $d f=1$ and $P<0.05$ ). These times are very similar to the time windows of amnesic action observed with 2-D-gal (Scholey et al. 1993). The second time window coincides with that for N-CAM antibodies (Scholey et al. 1993). As a control for the specificity of the effect to the L1 antibody we selected R4, one of our battery of chick synaptic membrane antibodies, which recognizes antigens with apparent molecular masses of 140,160, and $220 \mathrm{kD}$ (Mileusnic et al. 1995). Injections of R4 or of its preimmune serum at either $-30 \mathrm{~min}$ or $+5.5 \mathrm{hr}$ relative to training were without effect on retention tested at $24 \mathrm{hr}$. Retention after preimmune serum injection at $-30 \mathrm{~min}$ was $81 \%$ $(n=26)$, and R4 was 82\% $(n=24)$. After preimmune serum injection at $+5.5 \mathrm{hr}$, retention was 82\% $(n=24)$, and $\mathrm{R} 4$ was $79 \%(n=22)$. There were no significant differences in retention between the saline groups at any time tested.

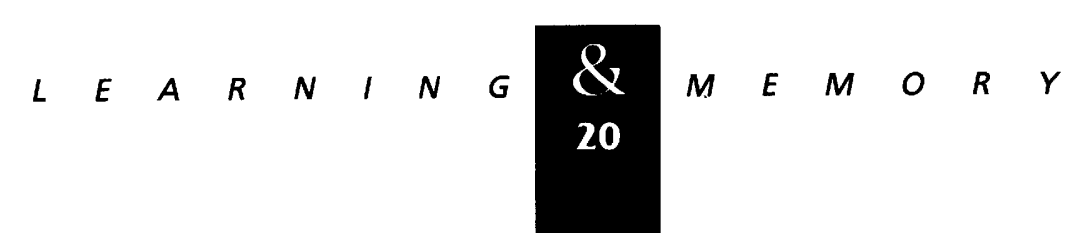




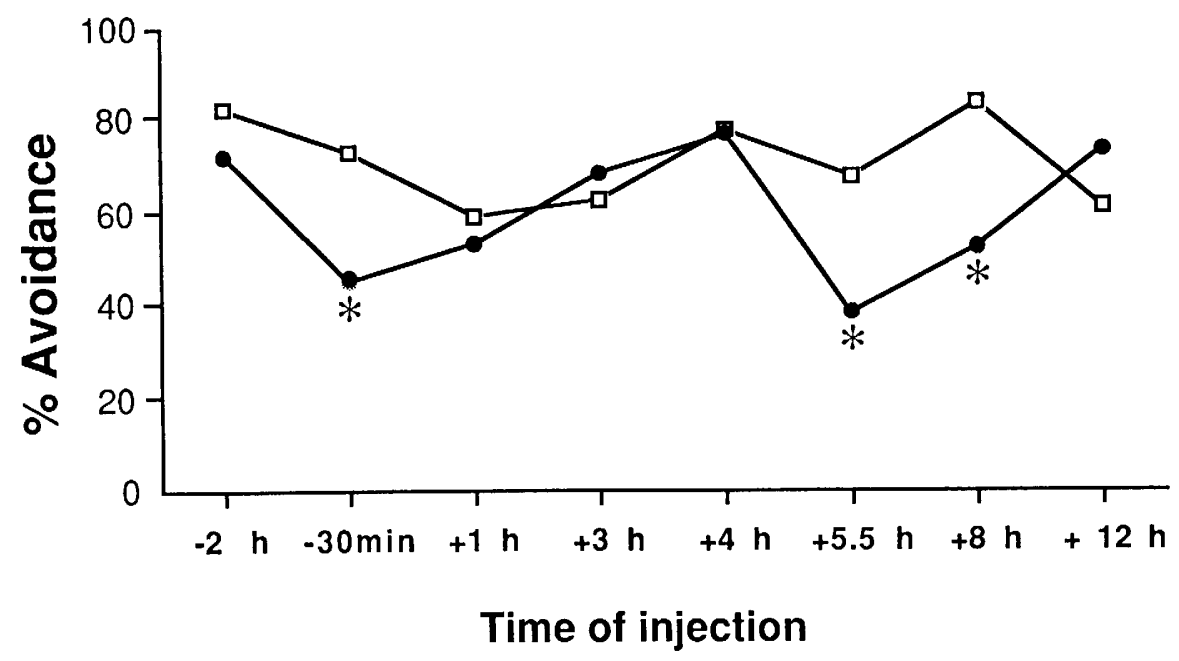

Figure 2: Effect of injections of chicken L: antibodies into the IMHV on percent avoidance (retention of memory) on a one-trial passive avoidance task. Each point represents a group of birds who received injections of L1 antibodies (anti-L1) (O) or saline ( $\square$ ) at the times relative to training indicated (see Materials and methods for numbers of animals in each group). All animals were tested at $24 \mathrm{hr}$ post-training $\left(^{*}\right) P<0.05$ between saline and antibody groups $\left(\chi^{2}\right)$.

\section{EFFECT OF INJECTIONS OF FRAGMENTS FN 1-5 AND IG I-VI}

To identify which parts of the extracellular domains of the L1 molecule might be most associated with the hypothesized synaptic remodeling following passive avoidance training, fragments $\mathrm{FN}$ 1-5 and Ig I-VI were injected intracranially at either the $-30 \mathrm{~min}$ or the $+5.5 \mathrm{hr}$ times relative to training, and chicks were tested for retention at 24 $\mathrm{hr}$ as they had been previously. As shown in Figure 3 , there was a clear distinction in the effects of the two fragments; amnesia was induced by Ig I-VI only when injected prior to training, and by FN 1-5 only when injected at $5.5 \mathrm{hr}$ post-training (Ig I-VI vs. saline injections at $-30 \mathrm{~min} \chi^{2}=4.39$; injections at $+5.5 \mathrm{hr} \chi^{2}=0.09$; FN1-5 vs. saline injections at $-30 \mathrm{~min} \chi^{2}=1.47$; injections at $+5.5 \mathrm{hr}, \chi^{2}=7.8$ ).

\section{Discussion}

Long-term memory for the passive avoidance response in day-old chicks requires a synaptic remodeling in IMHV and LPO that is dependent on the synthesis, transport, and insertion into the preand postsynaptic membranes of a number of glycoproteins. Enhanced protein and glycoprotein synthesis occurs in two waves, and it is, we propose, the second, occurring $5.5-8 \mathrm{hr}$ after the orig- inal learning event, which is required for consolidation of the memory trace. General inhibitors of terminal fucosylation of glycoproteins, such as 2-Dgal, produce amnesia when injected into the IMHV during either time window, whereas blocking the extracellular domain of N-CAM with an antibody only results in amnesia during the second wave (Scholey et al. 1993). This inhibition could occur by preventing N-CAM-dependent synaptic remodeling or by influencing second messenger cascades pre- and postsynaptically. The results reported here demonstrate that antibodies to the adhesion molecule $\mathrm{L} 1$ results in amnesia for passive avoidance when injected at times which coincide with the amnesic action of 2-D-gal.

That this amnesia is not a general consequence of the presence of the antibody is indicated by the fact that injection of the antibody at times outside the specific time windows was without effect on the behavior of the chicks. Furthermore, we have prepared a range of other antibodies to chick synaptic membrane glycoproteins, and of seven tested polyclonals, only that that recognize N-CAM produce amnesia (Mileusnic et al. 1995). Neither is preimmune serum amnesic (Scholey et al. 1993; Mileusnic et al. 1995). The results of Figure 2 suggest that the L1 antibodies do not influence synaptic activity in general but are specifically efective in inducing amnesia only at certain times after the training event. As a further control for the specificity of the effect of L1, antibody R4,

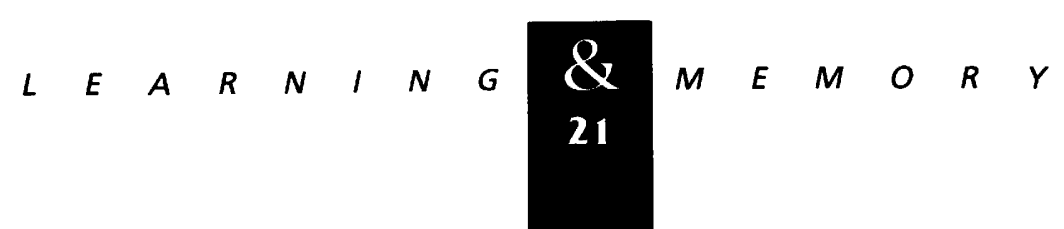


Scholey et al.
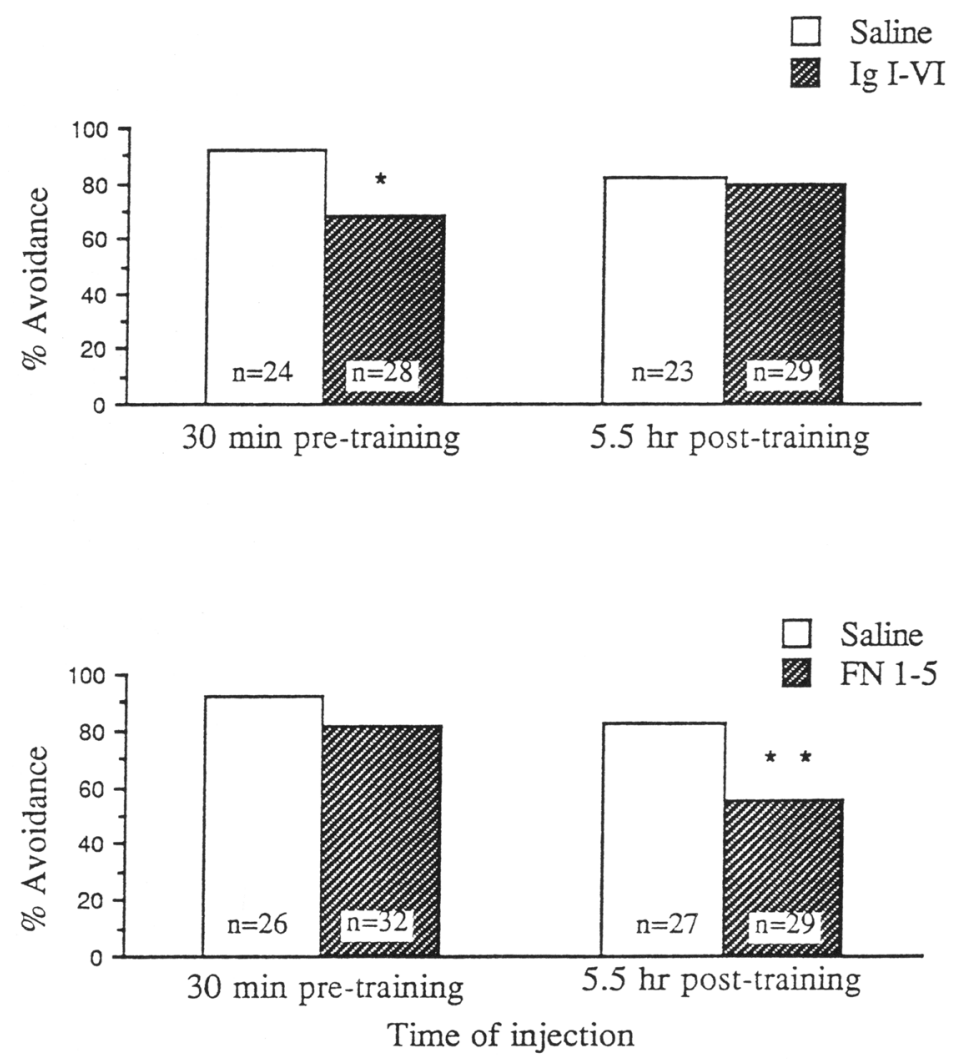

Figure 3: Effect of injections of $\mathrm{Ig} I-\mathrm{VI}$ and $\mathrm{FN} 1-5$ fragments at $-30 \mathrm{~min}$ and $+5.5 \mathrm{hr}$ on retention of memory for the passive avoidance task. All animals were tested at $24 \mathrm{hr}$ post-training. Numbers of animals in each group shown in the histograms (*) $P<0.05 ;\left({ }^{* *}\right) P<0.01$.

raised against a chick synaptic membrane fraction of $140-160 \mathrm{kD}$, which recognizes synaptic membrane antigens of molecular weight similar to that of L1, was injected at each of the two time windows during which anti-L1 antibodies produce amnesia, with negative results. Thus, some direct involvement of $L 1$ in time-dependent synaptic processing must be occurring during the normal stabilization of the long-term memory trace, both immediately following training and $5.5-8 \mathrm{hr}$ subsequently As with N-CAM, this effect could either be related to an inhibition of synaptic remodeling or it could be that by binding to endogenous L1 the antibody modifies some intracellular biochemical cascade.

In this respect the distinction in the effects of the two extracellular domain fragments FN1-5 and Ig I-VI is of considerable interest. This is the first difference in function to be described for the two fragments. Each has a similar effect on neuronal adhesion and neurite outgrowth of mouse cerebellar granule cells (Appel et al. 1993). Our data clearly show that the Ig I-VI fragment pro- duces amnesia only when injected at the earlier time point while the FN1-5 fragment gives amnesia only at the later time point. Although significant, the amnesic effect of the Ig I-VI fragment is not as great as that of the FN1-5 fragment (a 16\% loss of retention compared with a $33 \%$ loss); this may reflect a difference in binding affinity of the fragments or, alternatively, that at the earlier time point $\mathrm{L} 1$ is only one of a number of relevant synaptic membrane molecules. It is certainly tempting, however, to regard the effect of the anti-L1 at both time points as a summation of two distinct cellular, as well as behaviorally functional, processes. Nonetheless, the biochemical mechanisms that might be involved are unclear at present, because L1 may act both homophilically and heterophilically, and it is not known whether the two fragments differ from each other in this respect, or whether they have still other distinct functions. Further experiments in vitro will be necessary to distinguish these possibilities. The recent demonstration by Lüthli et al. (1994) that the development and stabilization of LTP in CA1 neurons of rat

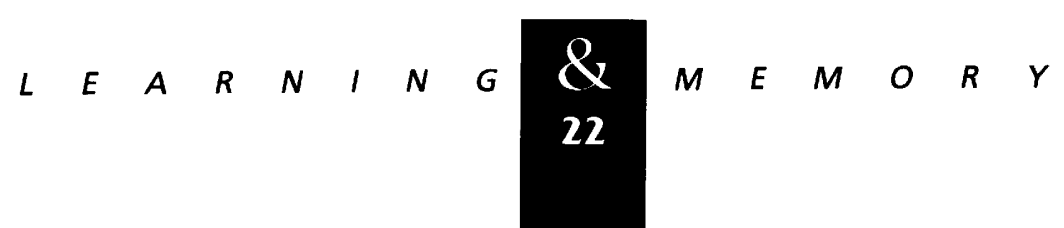


hippocampal slices is blocked by application of L1 or N-CAM antibodies and similar recombinant L1 fragments to those described in this paper encourages us to believe that these observations are revealing aspects of a general mechanism of memory-related synaptic remodeling.

As such antibodies can be detected in the chick forebrain for some hours after injection (Scholey et al. 1993), slowly diffusing from the injection site to other regions, the question of the specificity of the time at which injections produce amnesia is important; our hypothesis is that following injection, antibodies or fragments bind rapidly to available antigenic or homophilic sites; thus, the time windows at which the injections produce amnesia reflect the appearance at these times of additionally available binding sites generated during synaptic remodeling. Such an explanation would clearly also account for the differential effects of the two fragments, granted that they serve different functions within the cell recognition/neurite extension processes or modification of the intracellular response. Although the primary region of action is likely to be the IMHV, it cannot be ruled out that the effects are caused by binding to other forebrain regions to which the antibody diffuses.

The differential action of antibodies to L1 compared with those against N-CAM must reflect the diverse roles of the two proteins. Different effects of the two proteins, and antibodies recognizing them, on both cell type and on intracellular signaling have been well documented. Thus, certain CNS neurons, such as stellate basket cells of the mammalian cerebellum, appear not to express L1 but do express N-CAM (Persohn and Schachner 1987). The effects on different second messenger systems are also functionally discrete; in all cell types examined $\mathrm{L} 1$ and N-CAM affected inositol phosphate breakdown, levels of cellular calcium and changes in intracellular $\mathrm{pH}$, whereas levels of cAMP were raised in cerebellar neurons only, an effect not observed in response to N-CAM (von Bohlen und Halbach et al. 1992). Both L1 and N-CAM inhibit the phosphorylation of tyrosine residues in nerve growth cones (Atashi et al. 1992), a phenomenon that may be related to the stabilization of the neuronal cytoskeleton. It may be relevant that there is an increase in tyrosinated $\alpha$-tubulin immunoreactivity in both left IMHV and right LPO by $6 \mathrm{hr}$ post-training - an increase not apparent in these regions at $1 \mathrm{hr}$ post-training (Scholey et al. 1992) - and that may accompany the second wave of glycoprotein synthesis and could feasibly be mediated by both N-CAM and L1. Stabilization of the cytoskeleton at this time point would be consistent with our hypothesis that memory for passive avoidance training becomes "fixed" during the second wave. The involvement of L1 in both waves of glycoprotein synthesis and the involvement of N-CAM in only the second may be related to the finding that L1-dependent cellcell adhesion is enhanced in the presence of N-CAM (Kadmon et al. 1990). This lends support to a model in which a relatively short-term memory trace depends on L1-dependent mediations, presumably involving the immunoglobulin-like domain, whereas a lasting trace depends on the synergistic action of $\mathrm{L} 1$ and N-CAM some hours following training and requires the engagement of the fibronectin-like domain of L1. It is interesting in this respect that the $180-\mathrm{kD}$ isoform of N-CAM is accumulated in association with postsynaptic densities (Persohn et al. 1989) and may interact wiht L1 in preference to the other N-CAM isoforms (Pollerberg et al. 1990; Simon et al. 1991 ). N-CAM 180 appears to stabilize cell contacts by accumulating there and by interaction with the membrane-cytoskeletal linker protein spectrin (Pollerberg et al. 1986, 1987). The two different effects during the first and second memory waves may not necessarily be occurring in the same ensemble of cells, granted other results from our laboratory demonstrating that the processing sequences necessary for memory retention that appear be initiated in the left IMHV are, over the following $8 \mathrm{hr}$, also distributed to the right IMHV and to both left and right LPO (Rose 1991; Gigg et al. 1993, 1994).

\section{Acknowledgments}

This work was supported by the European Science Foundation (ESF) European Neuroscience Programme on the Neural Mechanisms of Learning and Memory and the Medical Research Council. We thank Vance Lemmon for 8D9 hybridoma cells, Guni Kadmon for antibodies, Juergen Holm for the L1 fragments, Christine Lancashire for technical help, and Steve Walters for care of the chicks.

The publication costs of this article were defrayed in part by payment of page charges. This article must therefore be hereby marked "advertisement" in accordance with 18 USC section 1734 solely to indicate this fact.

\section{References}

Appel, F., J. Holm, J.-F. Conscience, and M. Schachner. 1993. Several extracellular domains of the neural cell adhesion molecule $\mathrm{L} 1$ are involved in neurite outgrowth and cell body adhesion. J. Neurosci. 13: $4764-4775$.

$$
\text { n....... }
$$




\section{Scholey et al.}

Atashi, J.R., S.G. Klinz, C.A. Ingraham, W.T. Matten, M. Schachner, and P.F. Maness. 1992. Neural cell adhesion molecules modulate tyrosine phosphorylation of tubulin in growth cone membranes. Neuron 8: 831-842.

Barber, A.J. and S.P.R. Rose. 1991. Amnesia induced by 2-deoxygalactose in the day-old chick: Lateralization of effects in two different one-trial learning tasks. Behav. Neural Biol. 56: 77-88.

Bixby, J.L., J. Lilien, and L.F. Reichardt. 1988. Identification of the major proteins that promote neuronal process outgrowth on Schwann cells in vitro. J. Cell Biol. 107: 353-361.

Bullock, S., J. Potter, and S.P.R. Rose. 1990. Effects of the amnestic agent 2-deoxygalactose on incorporation of fucose into chick brain glycoproteins. J. Neurochem. 54: 135-142.

Bullock, S., S.P.R. Rose, and R. Zamani. 1992.

Characterization and regional localization of pre- and postsynaptic glycoproteins of the chick forebrain showing changed fucose incorporation following passive avoidance training. J. Neurochem. 58: 2145-2154.

Butchuladze, R., J. Potter, and S.P.R. Rose. 1990. Memory formation in the chick depends on membrane-bound protein kinase C. Brain Res. 535: 131-138.

Burnette, W.N. 1981. "Western blotting" electrophoretic transfer of proteins from sodium dodecyl sulphate-polyacrylamide gels to unmodified nitrocellulose and radiographic detection with antibody and radioiodinated protein A. A. Biochem. 112: 195-203.

Davis, J.L., K.M. Pico, and A. Cherkin. 1982. Memory enhancement induced in chicks by L-prolyl-L-leucyl-glycineamide. Pharmacol. Biochem. Behav. 17: 893-896.

Doyle, E., P. Nolan, R. Bell, and C.M. Regan. 1992. Neurodevelopmental events underlying information acquistion and storage. Network 3: 89-94.

Faissner, A., D.B. Teplow, D. Kubler, G. Keilhauer, V. Kinzel, and M. Schachner. 1985. Biosynthesis and membrane topography of the neural cell adhesion molecule L1. EMBO f. 4: 3105-3113.

Freeman, F.M., S.P.R. Rose, and A.B. Scholey. 1995. Two time windows of anisomyin-induced amnesia for passive avoidance training in the day-old chick. Behav. Neural Bio. (in press).

Gigg, J., T.A. Patterson, and S.P.R. Rose. 1993.

Training-induced increases in neuronal activity recorded from the forebrain of the day-old chick are time dependent. Neuroscience 56: 771-776.

1994. Increases in neuronal bursting recorded from the chick lobus parolfactorius after training are both time-dependent and memory-specific. Eur. I. Neurosci. 6: $313-319$.
Grumet, M. 1992. Structure, expression and function of $\mathrm{Ng}$-CAM, a member of the immunoglobulin superfamily involved in neuron-neuron and neuron-glia adhesion. /. Neurosci. Res. 31: 1-13.

Jork, R., G. Grecksch, and H.-J. Matthies. 1986. Impairment of hippocampal glycoprotein fucosylation-consequences on memory formation. In Learning and memory: Mechanisms of information storage in the nervous system (ed. H.-J. Matthies), pp. 223-228. Pergamon, Oxford, UK.

Kadmon, G., A. Kowitz, P. Altevogt, and M. Schachner. 1990. The neural cell adhesion molecule N-CAM enhances L1-dependent cell-cell adhesion. J. Cell Biol. 110: 193-208.

Keilhauer, G., A. Faissner, and M. Schachner. 1985. Differential inhibition of neurone-neurone, neurone-astrocyte and astrocyte-astrocyte adhesion by L1, L2 and N-CAM antibodies. Nature 316: 728-730.

Laemmli, U.K. 1970. Cleavage of structural proteins during the assembly of the head of bacteriophage T4. Nature 227: 146-148.

Lagenaur, C. and V. Lemmon. 1987. An L1-like molecule, the 8D9 antigen, is a potent substrate for neurite extension. Proc. Natl. Acad. Sci. 84: 7753-7757.

Lappuke, R., C.C.A. Bernard, M.E. Gibbs, K.T. Ng, and P.F. Bartlett. 1987. Inhibition of memory in the chick using a monoclonal anti-Thy-1 antibody. I. Neuroimmunol.

14: $317-324$.

Lemmon, V., K.L. Farr, nad C. Lagenaur. 1989. L1-mediated axon outgrowth occurs via homophilic binding mechanisms. Neuron 2: 1597-1603.

Linneman, D. and E. Bock. 1989. Cell adhesion molecules in neural development. Dev. Neurosci. 11: 149-173.

Lossner, B. and S.P.R. Rose. 1983. Passive avoidance training increases fucokinase activity in right forebrain base of day-old chicks. J. Neurochem. 41: 1357-1363.

Lüthli, A., J.-P. Laurent, A. Figurov, D. Muller, and M. Schachner. 1994. Hippocampal long-term potentiation and neural cell adhesion molecules L1 and NCAM. Nature 372: $777-779$.

Mileusnic, R., S.P.R. Rose, C. Lancashire, and S. Bullock. 1995. Characterisation of antibodies specific for chick brain NCAM which cause amnesia for a passive avoidance task. /. Neurochem. (in press).

Morgan, D.G. and A. Routtenberg. 1979. The incorporation of intrastriatally injected ${ }^{3} \mathrm{H}$-fucose into electrophoretically separated synaptosomal glycoproteins II. The effect of passive avoidance training. Brain Res. 179: 343-354.

Murakami, K., P.R. Gordon-Weeks, and S.P.R. Rose. 1986. Isolation of postsynaptic densities from day-old chicken brain. J. Neurochem. 46: 340-348. 
Orkand, P.M., J. Linder, and M. Schachner. 1984. Specificity of histotypic organization and synaptogenesis in reaggregating cell cultures of mouse cerebellum. Dev. Brain Res. 16: 119-134.

Persohn, E. and M. Schachner. 1987. Immunoelectron-microscopic localization of the neural cell adhesion molecules L1 and N-CAM during postnatal development of the mouse cerebellum. I. Cell Biol. 105: 569-576.

Persohn, E., G.E. Pollerberg, and M. Schachner. 1989. Immunoelectron-microscopic localization of the $180 \mathrm{kD}$ component of the neural cell adhesion molecule N-CAM in postsynaptic membranes. J. Comp. Neurol. 288: 92-100.

Piront, M.-L. and R. Schmidt. 1988. Inhibition of long-term memory formation by anti-ependymin antisera after active shock-avoidance learning goldfish. Brain Res. 442: 53-62.

Pollerberg, G.E., M. Schachner, and J. Davoust. 1986. Differentation state-dependent surface mobilities of two forms of the neural cell adhesion molecule. Nature 324: 462-465.

Pollerberg, G.E., K. Buridge, K. Krebs, S. Goodman, and M. Schachner. 1987. The $180 \mathrm{kD}$ component of the neural cell adhesion molecule N-CAM is involved in cell-cell contacts and cytoskeleton-membrane interactions. Cell Tissue Res. 250: $227-236$.

Pollerberg, G.E., J. Davoust, and M. Schachner. 1990. Lateral mobility of the cell adhesion molecule L1 within the surface membrane of morphologically undifferentiated and differentiated neuroblastoma cells. Eur. J. Neurosic. 2: 712-717.

Popov, N., S. Sculzek, W. Pohle, and H.-J. Matthies. 1981. Changes in the incorporation of ${ }^{3} \mathrm{H}$-fucose into rat hippocampus after acquisition of a brightness discrimination reaction: an electrophoretic study. Neuroscience 5: 61-167.

Rathjen, F.S. and M. Schachner. 1984. Immunocytological and biochemical characterization of a new neuronal cell surface component (L1 antigen) which is involved in cell adhesion. EMBO /. 3: 1-10.

Rose, S.P.R. 1989. Glycoprotein synthesis and postsynaptic remodelling in long-term memory formation. Neurochem. Int 14: 299-307.

1991. How chicks make memories: The cellular cascade from c-fos to dendritic remodelling. Trends Neurosci. 14: 390-397.

Rose, S.P.R. and R. Jork. 1987. Long-term memory in the chick is blocked by 2-deoxygalactose, a fucose analogue. Behav. Neural Biol. 48: 246-258.

Sadoul, K., R. Sadoul, A. Faissner, and M. Schachner. 1988. Biochemical characterization of different molecular forms of the neural cell adhesion molecule L1. I. Neurochem.

50: $510-521$.
Scholey, A.B., S. Bullock, and S.P.R. Rose. 1992. Passive avoidance training in the young chick results in time- and locus-specific evaluations of $\alpha$-tubulin immnoreactivity. Neurochem. Int. 21: 343-350.

Scholey, A.B., S.P.R. Rose, M.R. Zamani, E. Bock, and M. Schachner. 1993. A role for the neural cell adhesion molecule in a late, consolidating phase of glycoprotein synthesis six hours following passive avoidance training of the young chick. Neuroscience 55: 499-509.

Seilheimer, B. and M. Schachner. 1988. Studies of adhesion molecules mediating interactions between cells of peripheral nervous system indicate a major role for $\mathrm{L} 1$ in mediating sensory neuron growth on Schwann cells in culture. J. Cell Biol. 107: 341-351.

Simon, H., S. Klinz, T. Fahrig, and M. Schachner. 1991. Molecular association of the neural adhesion molecules L1 and N-CAM in the surface membrane of neuroblastoma cells is shown by chemical cross-linking. Eur. J. Neurosci. 3: $634-640$.

Sonderegger, P. and F.G. Rathjen. 1992. Regulation of axonal growth in the vertebrate nervous system by interactions between glycoproteins belonging to two subgroups of the immunoglobulin superfamily. J. Cell Biol. 119: $1387-1394$.

Stanton, P.K., J.M. Sarvey, and J.R. Moskal. 1987. Inhibition of the production and maintenance of long-term potentiation in rat hippocampal slices by a monoclonal antibody. Proc. Natl. Acad. Sci. 84: 1684-1688.

Staubli, U., P. Vanderklish, adn G. Lynch. 1990. Antagonists of the integrin receptor block long-term potentiation. Behav. Neural Biol. 53: 1-5.

Sukumar, R., S.P.R. Rose, and R.D. Burgoyne. 1980. Increased incorporation of $\left[{ }^{3} \mathrm{H}\right]$-fucose into chick brain glycoproteins following training on a passive avoidance task. J. Neurochem. 34: 1000-1006.

von Bohlen und F. Halbach, F., J. Taylor, and M. Schachner. 1992. Cell type-specific effects of the neural adhesion molecules $\mathrm{L} 1$ and $\mathrm{N}$-CAM on diverse second messenger systems. Eur. J. Neurosci. 4: 896-909.

Received November 14, 1995; accepted in revised form February 10, 1995.

$$
\begin{array}{lllllllllllllllll}
L & E & A & R & N & I & N & G & \begin{array}{l}
\ell \\
25
\end{array} & M & E & M & O & R & Y
\end{array}
$$




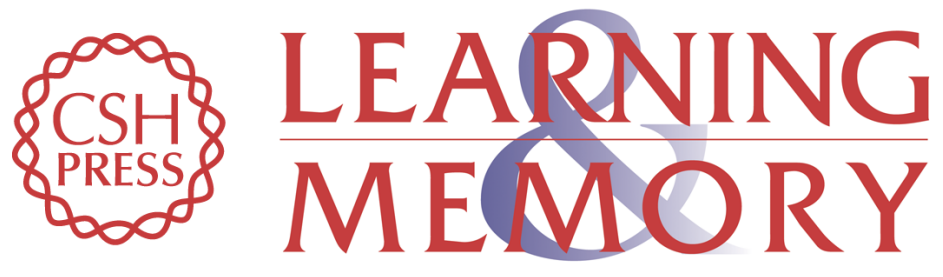

\section{A role for a chicken homolog of the neural cell adhesion molecule L1 in consolidation of memory for a passive avoidance task in the chick.}

A B Scholey, R Mileusnic, M Schachner, et al.

Learn. Mem. 1995, 2:

Access the most recent version at doi:10.1101//m.2.1.17

References This article cites 47 articles, 8 of which can be accessed free at: http://learnmem.cshlp.org/content/2/1/17.full.html\#ref-list-1

License

Email Alerting

Receive free email alerts when new articles cite this article - sign up in the box at the Service top right corner of the article or click here. 